\title{
IMPLEMENTASI PENDIDIKAN KARAKTER SISWA (Studi Kasus di SMP AL-HILAAL Desa Kamal KABUPATEN SERAM BAGIAN BARAT)
}

\author{
Jawaz Bagdad \\ jawazbagdad28@gmail.com \\ Amos Neolaka \\ amos_neolaka@yahoo.com \\ Erni Murniarti \\ erni.murniarti@uki.ac.id
}

\begin{abstract}
Abstrak
Tujuan penelitian ini bertujuan untuk mengetahui implementasi pendidikan karakter di SMP Al-Hilaal Kamal yang mana di dalamnya mencakup memahami dan menjelaskan tentang pelaksanaan pendidikan karakter.Menjelaskan kendala yang dihadapi serta strategi yang dilakukan dalam mengatasi kendala-kendala yang dihadapi.Metode penelitian adalah deskriptif kualitatif dengan pendekatan fenomenologi. Pengumpulan data dilakukan dengan cara observasi, wawancara, dan dokumentasi. Pemilihan informan menggunakan teknik purposive sampling yang terdiri dari kepala sekolah, guru mata pelajaran agama, dan guru mata pelajaran pkn.

Hasil penelitian ini adalah implementasi pendidikan karakter di SMP Al-Hilaal Kamal belum sepenuhnya efektif disebabkan oleh kurangnya kerjasama yang baik antara pihak sekolah dan pihak yayasan serta komite sekolah. Hal ini yang menyebabkan proses evaluasi pendidikan karakter kurang berjalan dengan baik karena tidak adanya dukungan dari yayasan dan komite sekolah. Solusi yang diberikan adalah pihak yayasan serta komite sekolah harus bersamasama dengan pihak sekolah untuk bekerjasama dalam mengawal proses pendidikan karakter baik dalam proses pelaksanaan sampai dengan proses evaluasi, dan ketiga pihak tersebut harus profesional, agar pelaksanaan pendidikan karakter bisa berjalan dengan efektif.
\end{abstract}

Kata Kunci : Implementasi, Pendidikan Karakter, Profesionalisme. 


\section{A. Pendahuluan}

\section{Latar Belakang}

Pendidikan saat ini adalah merupakan isu sentral yang menjadi pembicaraan dunia di era global saat ini dan dari waktu ke waktu terus dikembangkan. Hal ini dikarenakan pendidikan adalah merupakan poin dasar untuk memajukan suatu bangsa dan negara. Melalui pendidikan lah akan terlahir para insaninsan cerdas, bijak, dan berbudi pekerti mulia yang akan memajukan bangsa dan negara tersebut. Disamping itu, Perkembangan ilmu pengetahuan dan teknologi yang sangat terbuka saat ini tidak dapat dihindarkan dari aktivitas komunikasi secara tidak langsung (virtual) ke seluruh belahan dunia.maka dari itu hanya mereka yang siap lah yang bisa meraih kesempatan untuk bersaing di era global ini. Disamping itu, persoalan lingkungan hidup, revolusi ilmu pengetahuan, dan revolusi informasi akan menjadi tantangan masa depan tersendiri bagi seluruh umat manusia di muka bumi ini. Sehingga kondisi ini akan membuat situasi masyarakat akan mengalami metamorfosis untuk menuju masyarakat terbuka (open society).

Peranan pendidikan adalah sebuah solusi dan memegang peranan penting untuk merespons hal tersebut. Pendidikan untuk menciptakan masyarakat yang lebih baik dan dewasa,serta sebagai sarana untuk membina masyarakat yang hidup rukun, dan harmonis, serta terbebas dari segala bentuk teror kriminal, teror diskriminasi, dan sebagainya.

Koesoema (2012:26) mengemukakan bahwa pendidikan merupakan proses sosial yang bertujuan membantu peserta didik selaku generasi muda agar mengerti dengan baik tatanan sosial dalam masyarakat, mengerti pola perilaku, norma sopan santun dan tata krama yang dihargai dalam masyarakat. Kemudian ini dapat dilihat bahwa nantinya pada saat peserta didik terjun langsung ke dalam masyarakat, nantinya mereka tidak akan menemui kesulitan di dalam pergaulan di lingkungan sekitarnya.

Di Indonesia sendiri belakangan ini kita sering melihat berita melalui media informasi televisi, maupun koran, dan internet bahwa masih banyak terjadinya siswa yang tawuran, anak-anak yang dijadikan sebagai kurir narkoba, pelajar yang terjaring razia petugas saat penggerebekan penyakit masyarakat di hotel dan penginapan yang diduga melakukan hubungan (maaf) seks bebas, siswa yang diketahui hamil di luar nikah dan melakukan aborsi. Dan bahkan yang sangat mencengangkan adalah dengan mudahnya para pelajar bahkan anakanak yang dengan sangat mudah bisa memperoleh pil JCC yang sedang viral saat ini yang menurut para dokter dan ahli kesehatan bisa mengakibatkan hilang kesadaran dari pengguna bahkan sampai bisa mengakibatkan gila dan lebih buruknya mengakibatkan kematian. Lebih mirisnya lagi di daerah kota kendari, sulawesi tenggara, diduga yang meracik pil ini adalah apoteker yang notabene bertanggung jawab penuh terhadap hasil racikan obat tersebut yang tentunya hakikatnya untuk menyehatkan serta menyembuhkan masyarakat yang sedang membutuhkan pengobatan. Siapa yang tidak tergerus hatinya melihat fenomena ini terjadi di negara ini. 
Konstitusi negara Indonesia UUD Pasal 31 tentang pendidikan dan kebudayaan pada ayat 3 menyebutkan bahwa pemerintah mengusahakan dan menyelenggarakan satu sistem pendidikan nasional yang meningkatkan keimanan dan ketaqwaan serta akhlak mulia dalam rangka mencerdaskan kehidupan bangsa. Setelah itu dijabarkan dalam Undang-Undang Nomor 20, Tahun 2003 tentang Sistem Pendidikan Nasional disebutkan bahwa pendidikan adalah usaha sadar dan terencana untuk mewujudkan suasana belajar dan proses pembelajaran agar peserta didik secara aktif mengembangkan potensi dirinya untuk memiliki kekuatan spiritual keagamaan, pengendalian diri, kecerdasan, akhlak mulia, kepribadian serta keterampilan yang diperlukan dirinya, masyarakat, bangsa dan negara. Dalam penyusunan Standar Nasional Pendidikan pun disebutkan dalam salah satu fungsinya adalah bertujuan menjamin mutu pendidikan nasional dalam rangka mencerdaskan kehidupan bangsa dan membentuk watak serta peradaban bangsa yang bermartabat.Serta tujuan jangka panjang Nasional yang tertuang dalam Undang-Undang Nomor 17 Tahun 2007.Disini sudah terlihat jelas bahwa arah daripada tujuan penyelenggaraan pendidikan ini sangatlah mulia yakni ingin mewujudkan manusia yang bermartabat dan memiliki karakter mulia.

Pada masa Orde Baru pembentukan sikap serta perilaku yang sesuai dengan jiwa serta kepribadian Pancasila telah diwujudkan di dalam mata pelajaran PMP (Pendidikan Moral Pancasila) di sekolah.Dan secara non formal pun, pemerintah juga menyelenggarakan kegiatan penataran P4 (Pedoman Penghayatan dan Pengamalan Pancasila) bagi seluruh masyarakat.Pendidikan Moral Pancasila ini merupakan pendidikan moral khas bangsa Indonesia, yang berusaha untuk menanamkan nilai-nilai budi pekerti luhur yang terkandung di dalam Pancasila kepada seluruh peserta didik sebagai warga negara Indonesia. Fakta yang terjadi justru jauh berbanding terbalik dengan apa yang diharapkan dari amanat Undang-Undang serta kebijakan-kebijakan yang telah pemerintah tetapkan demi terwujudnya individu-individu Indonesia yang mampu dan berkualitas di bidang akademik dan sekaligus memiliki kepribadian serta moral yang baik pula.

Bukan hal yang tabu yang terjadi di masyarakat Indonesia bahwa seseorang atau siswa itu dianggap berhasil jika memiliki nilai atau kemampuan akademik yang baik pula, dan demikian seseorang atau siswa jika memiliki kemampuan akademik yang kurang baik maka dia akan mendapatkan penilaian yang kurang baik. Hal ini dapat dilihat bahwa di dalam persepsi masyarakat Indonesia pada umumnya lebih menempatkan aspek kognitif daripada aspek sikap dan nilai (afektif).Padahal fakta yang terjadi saat ini di Indonesia justru orang yang rata-rata memiliki kemampuan akademik lah yang sekarang ini justru tersandung masalah-masalah yang berkaitan dengan masalah hukum.Dari situlah sekarang kita harus melihat bahwa ranah sikap dan nilai juga tidak bisa diabaikan begitu saja, kemampuan kognitif juga harus diimbangi dengan kemampuan afektif agar bisa mencapai standar yang bermuara kepada amanat Undang-Undang tersebut. 
Menanggapi hal tersebut, sebagai bukti keseriusan pemerintah terbaru juga Presiden Republik Indonesia Bapak Ir. Joko Widodo menerbitkan Peraturan Presiden (Perpres) No 87 Tahun 2017 mengenai Penguatan Pendidikan Karakter. Sehingga nanti harapannya akan terjadi revolusi Karakter besarbesaran terhadap bangsa Indonesia kedepannya.

SMP Al-Hilaal Kamal, adalah merupakan salah satu sekolah menengah pertama yang bertempat di desa Kamal, Kecamatan Kairatu Barat, Kabupaten Seram Bagian Barat Provinsi Maluku. Berdasarkan tujuan dari amanat Undang-Undang serta Perpres No 87 Tahun 2017 tersebut SMP Al Hilaal Kamal Kabupaten Seram Bagian Barat, sebagai salah satu lembaga pelaksana pendidikan juga ikut serta menjalankan Pendidikan Karakter. Berdasarkan hasil pengamatan yang dilakukan dengan cara mencari informasi awal mengenai aktifitas siswa di sekolah ini, terdapat masalah-masalah pendidikan karakter, diantaranya ditemukan bahwa masih terdapat siswa yang sering membolos sekolah, kurangnya sikap bertoleransi terhadap perbedaan, masih adanya sejumlah siswa yang tidak melaksanakan ibadah, masih terdapat siswa yang suka berlaku curang pada saat ujian, dan sebagainya.

\section{Fokus Penelitian}

Dalam penelitian ini yang menjadi focus peneliti adalah pendidikan karakter. Yang dimana hasil penelitian awal dilakukan dengan cara mencari informasi mengenai aktifitas siswa di sekolah dari penjual jajanan di sekitar sekolah, serta warga yang berada disekitaran sekolah, bahwa terdapat masalah-masalah pendidikan karakter. Berdasarkan fokus tersebut penelitian ini pada bagaimana implementasi pendidikan karakter, maka disusunlah sub fokus, diantaranya :

1. Implementasi pendidikan karakter di sekolah

2. Pemahaman nilai-nilai karakter di sekolah

3. Pendidikan agama di sekolah

4. Pendidikan keragaman atau multicultural di sekolah

5. Evaluasi pendidikan karakter

\section{Rumusan Masalah}

Berdasarkan sub fokus penelitian, dapat dirumuskan masalah sebagai berikut :

a. Bagaimana pendidikan karakter siswa di SMP Al-Hilaal Kamal, Kabupaten Seram Bagian Barat?

b. Bagaimana pemahaman nilai-nilai karakter di SMP Al-Hilaal Kamal, Kabupaten Seram Bagian Barat?

c. Bagaimana pendidikan agama di SMP Al-Hilaal Kamal, Kabupaten Seram Bagian Barat?

d. Bagaimana pendidikan multicultural di SMP Al-Hilaal Kamal, Kabupaten Seram Bagian Barat?

e. Bagaimana evaluasi pendidikan karakter di SMP Al-Hilaal Kamal, Kabupaten Seram Bagian Barat? 


\section{Tujuan Penelitian}

Adapun tujuan dari penelitian ini adalah untuk mengetahui Implementasi Pendidikan Karakter pada SMP Al-Hilaal Kamal Kabupaten Seram Bagian Barat, Provinsi Maluku yang di dalamnya mencakup memahami dan menjelaskan pelaksanaan Pendidikan Karakter pada SMP Al-Hilaal Kamal Kabupaten Seram Bagian Barat, dan memahami kendala pelaksanaan Pendidikan Karakter pada SMP Al-Hilaal Kamal Kabupaten Seram Bagian Barat, serta mengetahui strategi untuk mengatasi kendala-kendala yang dihadapi di dalam pelaksanaan Pendidikan Karakter pada SMP Al-Hilaal Kamal Kabupaten Seram Bagian Barat.

\section{Paradigma}

Paradigma sebagai penetapan Fokus penelitian ini adalah sebuah penelitian baiknya dilakukan terhadap sesuatu hal yang nyata atau sesuatu yang benarbenar terjadi.Penerapan pendidikan karakter di sebuah sekolah adalah merupakan jawaban atas upaya pemerintah untuk mewujudkan pendidikan yang baik dan berbasis karakter, serta oleh Presiden Republik Indonesia mencanangkan revolusi mental. Sekolah merupakan lembaga pendidikan yang akan membentuk peserta didik menjadi insan yang cerdas dan berakhlak mulia. Penelitian ini berdasarkan paradigma ilmiah yang mengacu kepada pandangan fenomenologis yakni semua hal yang berkaitan dengan implementasi pendidikan karakter di SMP Al-Hilaal desa Kamal Kabupaten Seram Bagian Barat.

\section{Manfaat Penelitian}

Adapun manfaat dalam penelitian iniadalah sebagai berikut :

1. Manfaat praktis, Bagi penulis manfaat praktis yang diharapkan adalah bahwa seluruh tahapan penelitian serta hasil penelitian yang diperoleh dapat memperluas dan sekaliugus memperoleh pengetahuan empirik mengenai penerapan pendidikan karakter. Bagi pihak-pihak yang terkait dalam penelitian ini dalam hal ini SMP-Al Hilaal Kamal Kabupaten Seram Bagian Barat, maupun Dinas Pendidikan Kabupaten Seram Bagian Barat Provinsi Maluku, manfaat dari hasil penelitian ini dapat diterima dan dipertimbangkan sebagai kontribusi untuk meningkatkan pelaksanaan pendidikan karakter di ruang lingkup lembaga pelaksana pendidikan agar bisa lebih berjalan dengan maksimal.

2. Manfaat akademis yang diharapkan adalah hasil penelitian ini dapat dijadikan rujukan bagi upaya penerapan kebijakan pendidikan karakter, serta berguna sebagai bahan referensi bagi peneliti-peneliti yang akan melakukan penelitian tentang penerapan pendidikan karakter berikutnya.

\section{B. Metode Penelitian}

Moleong (2009:6) menjelaskan bahwa penelitian kualitatif adalah penelitian yang bermaksud untuk memahami fenomena tentang apa yang dialami oleh subyek penelitian,misalnya perilaku,persepsi, motivasi, tindakan dan lain-lain. Secara holistik dan dengan cara deskriptif dalam bentuk kata-kata dan bahasa 
pada suatu kontek khusus yang alamiah dan dengan memanfaatkan berbagai metode ilmiah.

Dalam penelitian ini, peneliti menggunakan metode deskriptif kualitatif. Karena mengacu kepada pendapat Burhan Bungin (2007:68) yang mengemukakan bahwa format deskriptif kualitatif dilakukan pada penelitian studi kasus dan memusatkan penelitian pada suatu unit tertentu sehingga memungkinkan penelitian bersifat mendalam terutama dalam pengumpulan data. Dengan demikian, format deskriptif kualitatif lebih tepat apabila digunakan untuk meneliti masalah-masalah yang membutuhkan studi mendalam, seperti permasalahan implementasi publik di masyarakat, dan sebagainya.

\section{Populasi dan Sampel}

Populasi dalam penelitian ini merupakan wilayah yang ingin di teliti oleh peneliti.Seperti menurut Sugiyono (2013: 80) "Populasi adalah wilayah generalisasi yang terdiri atas obyek atau subyek yang mempunyai kualitas atau karakteristik tertentu yang ditetapkan oleh peneliti untuk dipelajari dan ditarik kesimpulannya".Pendapat diatas tersebut menjadi acuan bagi penulis untuk menentukan populasi.Populasi yang digunakan sebagai penelitian ini adalah Komponen SMP Al-Hilaal Kamal.

Menurut Sugiyono (2011: 80) “Sampel adalah bagian dari jumlah dan karakteristik yang dimiliki oleh populasi tersebut". Dalam penelitian ini peneliti menggunakan teknik purposive sampling. Menurut Wea (2016) dalam Fuad dan Nugroho (2014: 58), penentuan sumber data pada orang yang diwawancarai dilakukan secara purposive sampling yaitu informan-informan yang peneliti tentukan merupakan orang - orang yang menurut peneliti memiliki informasi yang dibutuhkan dalam peneliti ini informan dalam peneliti ini berjumlah 3 orang yakni Kepala Sekolah, Guru Pendidikan Agama, dan Guru PKN.

\section{Teknik Analisis Data}

Analisis data adalah proses mencari dan menyusun secara sistematis data yang diperoleh dari hasil wawancara, catatan lapangan, dan bahan - bahan lain, sehingga dapat mudah dipahami dan temuannya dapat diinformasikan kepada orang lain (Bogdan dalam Sugiyono, 2013: 244).

Proses analisis data kualitatif berlangsung selama proses pengumpulan data secara interaktif, sehinggah datanya sudah jenuh. Tehnik analisis data dilakukan dengan cara penyajian data, reduksi data, dan penarikan kesimpulan. Aktivitas dalam analisis data yaitu data reduction (merangkum dan memilih hal-hal pokok), data display (membuat uraian singkat, bagan, hubungan antara kategori, dan sejenisnya), dan conclusion drawing/verification (penarikan kesimpulan).

\section{Hasil Penelitian dan Pembahasan \\ 1. Temuan Penelitian}

\section{a. Implementasi Pendidikan Karakter}

Hasil temuan penelitian Implementasi Pendidikan Karakter ada 5 yaitu : 
1. Pemahaman pendidikan karakter oleh komponen pengajar di sekolah akan sangat berperan penting terhadap penerapan pendidikan karakter di sekolah itu sendiri.

2. Latar belakang dalam hal perencanaan diterapkannya pendidikan karakter harus di analisis sedetail mungkin, sehingga di dalam penerapannya sesuai dengan hasil yang benar-benar diinginkan, guna menghindari kerancuan dan kesenjangan dalam penerapan pendidikan karakter itu sendiri.

3. Lama dan tidaknya penerapan pendidikan karakter bukanlah menjadi sebuah ukuran keberhasilan penerapannya, melainkan proses yang baik dan benar serta evaluasi secara berkesinambungan.

4. Kegiatan Ekstrakurikuler bisa menjadi alternatif persiapan yang dilakukan dalam penerapan pendidikan karakter selain persiapan di perangkat pengajaran.

5. Diperlukan kerjasama oleh para komponen sekolah untuk mengatasi adanya siswa yang masih suka membolos.

\section{b. Pemahaman Nilai Karakter}

Hasil temuan penelitian Pemahaman Nilai Karakter terdapat 4 bagian yang diantaranya

1. Pihak sekolah sudah memahami nilai-nilai karakter yang esensial dan telah diterapkan maupun diajarkan kepada siswa namun belum semua siswa mempraktikkannya.

2. Para guru harus bisa lebih kreatif di dalam mengintegrasikan pendidikan karakter di dalam perangkat pengajaran agar siswa tidak merasa jenuh dan bosan.

3. Bimbingan konseling diperlukan untuk pemahaman nilai-nilai karakter.

4. Kerjasama yang baik dalam lingkungan pendidikan akan mendukung efektifitas penanaman nilai-nilai karakter.

\section{c. Pendidikan Agama di Sekolah}

Hasil temuan penelitian pendidikan agama disekolah terdapat 5 bagian yaitu :

1. Mengembangkan pembelajaran dengan cara mengajak siswa langsung ke dalam proses pengamalan ajaran agama akan sangat lebih baik, karena dengan demikian hal itu bisa menggiring opini para siswa bahwa yang diajarkan bukan hanya konsep semata, namun sejalan dengan praktik.

2. Terdapat banyak nilai-nilai karakter yang dapat ditanamkan dalam pendidikan agama.

3. Evaluasi terhadap proses pemisahan ruang belajar pada mata pelajaran agama terhadap siswa tertentu harus dilakukan, agar menghindari opini para siswa yang merasa dibeda-bedakan.

4. Sarana peribadatan harus difungsikan untuk hal-hal baik lainnya, yakni tempat bimbingan konseling, maupun praktek keagamaan lainnya. 
5. Menjalin hubungan yang baik dengan masyarakat sekitar sekolah perlu diperhatikan supaya bisa sama-sama mengawal berjalannya pendidikan yang baik.

\section{d. Pendidikan Mutlikultural}

Hasil temuan penelitian pendidikan multicultural terdapat 2 bagian yaitu :

1. Sikap toleransi terhadap keberagaman telah berjalan dengan sangat baik di sekolah ini.

2. Sekolah harus merespon sikap toleransi terhadap keberagaman ini menjadikannya sebagai contoh yang dapat dilihat oleh masyarakat luas dan sekolah lainnya, melalui kegiatan ekstrakurikuler maupun lainnya.

\section{e. Evaluasi Pendidikan Karakter}

Hasil temuan penelitian evaluasi pendidikan karakter, terdapat 6 bagian yaitu :

1. Pendidikan karakter telah berjalan dengan baik dan evaluasi dilakukan setiap akhir semester.

2. Tenaga pengajar yang berkualitas dan kreatif.

3. Infrastruktur dalam hal ini bangunan sekolah maupun ruangan pelengkap lainnya harus dibenahi agar tingkat kenyamanan siswa di sekolah lebih baik dan penerapan pendidikan karakter dapat berjalan dengan baik.

4. Tidak adanya kerjasama yang baik antara pihak sekolah, yayasan, dan komite.

5. Kerjasama antara pihak sekolah, yayasan, dan komite sekolah harus dibangun dan diperkuat agar setiap masalah yang muncul di dalam penerapan pendidikan karakter dapat dicarikan solusi secara bersamasama dan juga menyebabkan terciptanya kondisi organisasi yang sehat.

6. Hasil evaluasi terhadap penerapan pendidikan karakter harus ditindak lanjuti dengan keputusan-keputusan bersama yang telah disepakati oleh pihak sekolah, yayasan, dan komite sekolah.

\section{Pembahasan Hasil Penelitian}

Setelah melakukan penelitian, kemudian peneliti akan berusaha membahas hasil penelitian yang berkaitan dengan temuan hasil penelitian sebagai berikut:

\section{a. Implementasi Pendidikan Karakter}

Implementasi pendidikan karakter pada SMP Al-Hilaal Kamal, sekolah ini sudah lama menerapkan pendidikan karakter, selain itu Visi dan Misi sekolah juga mendukung terwujudnya pendidikan karakter, dimana Visi sekolah adalah "menjadikan sekolah berprestasi dalam akademik, berbudaya, dan beriman serta taat kepada ajaran agama yang dianut".

\section{Pemahaman Pendidikan Karakter}

Untuk mewujudkan pendidikan karakter yang baik serta berkualitas, dibutuhkan pemahaman tentang konsep yang baik atas pendidikan karakter 
sebelum diterapkan kepada para peserta didik.Sudah barang tentu tidak bisa menerapkan pendidikan karakter sementara pihak perencana dan penyelenggara pendidikan karakter tidak begitu memahami secara baik tentang bagaimana pendidikan karakter itu sendiri.Kepala sekolah dan para guru adalah merupakan personalia penting di dalam pendidikan karakter di sekolah. Sementara itu interaksi yang intens terjadi di sekolah adalah tidak lain interaksi antara guru dengan para peserta didik, baik itu berkaitan dalam hal proses pembelajaran di kelas maupun kegiatan kurikuler lainnya. Di sekolah ini, pemahaman tentang konsep pendidikan karakter oleh guru belum terlalu baik sehingga di dalam penerapannya pun masih belum terlalu maksimal.Oleh karena itu, pemahaman guru yang baik tentang konsep pendidikan karakter haruslah diperkuat agar penerapan pendidikan karakter itu dapat berjalan dengan baik serta tepat sasaran dan tujuannya berdasarkan konsep pendidikan karakter.Karenanya tidak salah jika menempatkan pemahaman konsep pendidikan karakter sebagai salah satu instrumen penting di dalam penerapan pendidikan karakter.

\section{Perencanaan Pendidikan Karakter}

Perencanaan yang baik adalah salah satu indikator keberhasilan penerapan pendidikan karakter.Latar belakang diterapkannya pendidikan karakter di sekolah ini adalah faktor lingkungan, dimana karakteristik masyarakat maluku pada umumnya berwatak keras, terbentuk dengan lingkungan yang kasar, sehingga di dalam kehidupan sosial bermasyarakatpun anak dengan sendirinya terbentuk untuk merespon karakter tersebut.Perumusan latar belakang penerapan pendidikan karakter juga merupakan salah satu faktor penting untuk mendukung keberhasilan pendidikan karakter, dimana hal itu bertujuan untuk menetapkan akar dari masalah yang ingin dipecahkan.

Persiapan yang baik serta matang juga diperlukan untuk mencapai hasil yang maksimal untuk implementasi pendidikan karakter itu sendiri.Di sekolah ini tidak ada persiapan khusus untuk penerapan pendidikan karakter seperti pernyataan dari beberapa narasumber tersebut, melainkan persiapan hanya sebatas ditujukan kepada perangkat pengajaran baik itu dalam menentukan indikator yang ingin dicapai oleh para peserta didik.Untuk mendapatkan hasil yang maksimal kepala sekolah serta guru harus bisa mempersiapkan hal-hal maupun semua yang diperlukan.

\section{Aktualisasi Pendidikan Karakter}

Aktualisasi pendidikan karakter di SMP Al-Hilaal Kamal ini telah lama diterapkan, bahkan sejak sekolah ini berdiri telah diterapkan pendidikan karakter.Namun dari segi hasil dapat dikatakan tingkat keberhasilan penerapan pendidikan karakter ini dalam kategori baik, namun tidak dapat dipungkiri bahwa masih terdapat beberapa siswa yang masih suka membolos sekolah, fakta ini membuktikan bahwa lama atau tidaknya penerapan pendidikan karakter belum bisa menjamin keberhasilan penerapan pendidikan karakter itu sendiri.hal ini yang oleh pihak sekolah mesti digaris bawahi serta diperhatikan dan selanjutnya harus mencari solusi untuk memecahkan masalah tersebut. Kerjasama yang baik antara 
komponen sekolah serta warga sekolah dapat dioptimalkan untuk mencegah hal tersebut.

\section{b. Pemahaman Nilai Karakter}

Pemahaman Nilai-Nilai Karakter di SMP Al-Hilaal Kamal Kabupaten Seram Bagian Barat dikategorikan baik, karena sebagian besar siswa merespon positif sendiri pendidikan karakter ini.Namun belum semua siswa mengimplementasikan nilai-nilai pendidikan karakter.

\section{Pemahaman dan Realisasi Nilai-nilai Karakter Esensial}

Pemahaman tentang nilai-nilai karakter yang esensial sudah sangat baik dipahami, hal ini dilihat dari banyaknya siswa yang mengimplementasikan nilai-nilai karakter itu ke dalam kehidupan baik di sekolah maupun di lingkungan masyarakat.Namun yang menjadi kendala adalah belum semua siswa mengimplementasikan hal tersebut.Jika dikaitkan dengan lamanya penerapan pendidikan karakter, haruslah hasil seperti ini bisa diminimalisir oleh pihak perancang dalam hal ini pihak sekolah, ada beberapa hal yang perlu diperhatikan dan dilakukan dalam upaya untuk memelihara dan menanamkan serta membuat siswa dapat mengimplementasikan nilai-nilai karakter yang esensial, antara lain :

1. Guru harus lebih kreatif untuk mencarikan cara di dalam menangani masalah tersebut, karena tidak efektif jika hanya mengandalkan setiap pertemuan di kelas untuk melakukan bimbingan terhadap siswa yang belum mengimplementasikan nilai-nilai karakter tersebut.

2. Pihak Sekolah harus menyediakan guru Bimbingan Konseling, agar segala upaya yang berkaitan dengan konseling terhadap permasalahan para siswa lebih spesifik dan lebih mengena.

3. Komunikasi dan kerjasama antara lingkup sekolah agar bisa samasama mengawal terlaksananya pemahaman dan penerapan nilainilai karakter esensial ini.

4. Guru sebagai role model, sehingga siswa akan menjadikan guru sebagai panutan di dalam berpikir dan bertindak.

Dengan diterapkannya beberapa hal tersebut, diharapkan pemahaman serta penerapan nilai-nilai karakter esensial oleh para siswa akan lebih baik dan menjadikannya lebih baik lagi.

\section{Penanaman Pendidikan Karakter Melalui Semua Mata Pelajaran}

Penanaman pendidikan karakter dalam semua mata pelajaran sangat efektif untuk mendukung penerapan pendidikan karakter, karena di dalam setiap saat pertemuan pembelajaran di kelas setiap saatnya pasti para siswa akan bertemu dengan penanaman nilai-nilai karakter. Hal ini juga dapat dilihat hasil dari penanaman nilai-nilai karakter pada semua mata pelajaran yang diterapkan di SMP Al-Hilaal Kamal ini, sebagian besar siswa menunjukkan respon positif dan sebagian kecil diantaranya masih belum menunjukkan respon yang baik. Untuk bisa memecahkan masalah ini pihak sekolah perlu memperhatikan beberapa hal berikut, diantaranya : 
1. Materi-materi dalam mata pelajaran harus terlebih dahulu dianalisis nilai-nilai karakternya.

2. Metode penanaman yang baik oleh para guru mata pelajaran.

3. RPP dan Silabus haruslah berkarakter.

4. Media pembelajaran yang berbasis karakter.

5. Guru dan kepala sekolah harus melakukan evaluasi terhadap penanaman nilai-nilai karakter esensial ini.

Beberapa langkah tersebut akan sangat berkontribusi positif terhadap pemahaman nilai-nilai karakter di sekolah, namun semua itu tidak akan membuahkan hasil yang baik jika tidak dijalankan dengan baik dan benar.

\section{Penanaman Karakter Secara Berkelanjutan}

Penanaman nilai-nilai karakter secara berkelanjutan sangatlah diperlukan untuk tetap menjaga dan memelihara mindset para siswa untuk tetap berada pada nilai-nilai karakter baik, setiap jenjang pendidikan adalah merupakan suatu jarak yang mesti diperhatikan, perubahan pola fikir, fisik, dan lingkungan pergaulan baru adalah merupakan tantangan tersendiri bagi para pihak sekolah agar tetap berada pada jalur yang baik dan benar. Maka pada kondisi ini, komunikasi serta koordinasi pada tingkat lingkungan rayon pendidikan di setiap jenjang pendidikan mesti diperkuat.Evaluasi secara bersama dan dilakukan secara berkala dapat membantu pihak sekolah untuk terus memantau dan mengawal penanaman nilai-nilai karakter dalam setiap jenjang dalam lingkup pendidikan di rayon.

\section{c. Pendidikan Agama di Sekolah}

Pendidikan Agama merupakan salah satu poros penting pemegang peranan di dalam penanaman pendidikan karakter, karena di dalamnya terkandung nilai-nilai agama yang sangat berbanding lurus dengan nilai-nilai karakter yang baik.Pendidikan agama di SMP Al-Hilaal Kamal sangatlah berkontribusi posistif terhadap penerapan pendidikan karakter di sekolah ini.

\section{Penanaman Nilai -Nilai Agama}

Terdapat banyak sekali nilai-nilai agama yang dapat ditanamkan kepada para siswa yang mengandung nilai-nilai karkter positif.Diantaranya sikap jujur, bertanggung jawab, pengamalan ajaran agama, disiplin, kebersihan dan lain-lain.Penanaman nilai-nilai agama ini dianggap penting karena adalah merupakan pendidikan agama ini juga adalah merupakan sebuah pendukung terhadap penerapan pendidikan karakter karena nilai-nilai yang ditanamkan memang sejalan dengan nilai-nilai pendidikan karakter.

Penanaman nilai-nilai agama pada mata pelajaran Agama di SMP Al-Hilaal Kamal sudah berjalan seperti yang diharapkan dimana pada dasarnya setiap pertemuan pembahasan memang menanamkan nilai-nilai karakter dalam pelajaran agama.

\section{Tujuan Pendidikan Karakter Dalam Pembelajaran Agama}


Tujuan pendidikan karakter dalam pembelajaran agama sangatlah penting diketahui untuk lebih mempertajam analisa kebutuhan pendidikan karakter melalui pembelajaran agama di sekolah.Di SMP Al-Hilaal Kamal ini guru memaknai tujuan pendidikan karakter dalam pembelajaran agama dimana pendidikan agama ditempatkan sebagai salah satu mata pelajaran pendukung untuk terlaksananya pendidikan karakter itu sendiri.

Nilai-nilai yang diajarkan di dalam pendidikan agama lebih sama dengan apa yang menjadi nilai-nilai karakter. Sehingga hal itu bertujuan untuk menciptakan generasi yang berakhlak mulia baik itu di dunia maupun di akhirat.

\section{Mengamalkan Ajaran Agama}

SMP Al-Hilaal Kamal ini telah memiliki sebuah masjid yang difungsikan untuk melaksanakan ajaran agama.Keberadaan sebuah masjid ini juga sangat membantu penerapan pendidikan karakter ini.Secara umum pengamalan ajaran agama ini pun sejalan dengan nilai-nilai pendidikan karakter, jadi dapat dilihat bahwa implementasi oleh para siswa ini bisa digolongkan di dalam kategori baik. Untuk lebih memaksimalkannya lagi, ada beberapa hal-hal yang bisa dibuat untuk pengamalan ajaran agama di dalam pendidikan agama di sekolah, diantaranya :

1. Sarana peribadatan ini harus juga difungsikan untuk kegiatan keagamaan lainnya, misalnya pihak sekolah membuat kegiatan yang bernuansa keagamaan misalnya perayaaan hari-hari besar kegamaan dan lain-lain.

2. Bimbingan konseling terhadap siswa juga bisa dilakukan di tempat ibadah ini, misalnya pada saat selesai sholat berjamaah kemudian guru bisa sedikit memberikan nasihat dan sebagainya.

3. Guru harus kreatif untuk mengembangkan pembelajaran dengan cara membimbing siswa untuk mengamalkan ajaran agama secara langsung.

Keberadaan sebuah tempat ibadah ini bisa juga menjadi penting karena jika para siswa melakukan kegiatan ekstra kurikuler di dalamnya juga akan membantu sikap positif yang terkandung di dalam kegiatan-kegiatan yang dipusatkan sarana prasarana yang menunjang pengamalan ajaran agama tersebut.

\section{Pendidikan Agama di Sekolah Memperhatikan Etika Sosial}

Pendidikan Agama di sekolah sebagai salah satu penunjang nilai-nilai karakter juga di dalam penerapannya harus memperhatikan kondisi sosial yang berada di sekitarnya, baik itu kondisi geografis, kultur, sosial, budaya, agama, dan lain sebagainya. Di sekolah ini, juga sangat memperhatikan kondisi sosial maupun etika-etika sosial yang ada pada lingkungannya.

Perbedaan Agama merupakan salah satu yang di respon, baik antara guru, maupun antara para siswa dalam ruang lingkup SMP Al-Hilaal Kamal ini. Respon yang diperlihatkan sudah sangat baik, namun yang perlu di evaluasi kembali adalah pihak sekolah harus bagaimana bisa untuk tidak memilah-milah siswa pada saat mata pelajaran agama berlangsung, 
mungkin memang harus dilakukan, namun pihak sekolah juga harus menghindari pemikiran siswa bahwa ada perlakuan khusus dalam hal ini aspek mayoritas-minoritas. Apalagi provinsi maluku pernah dilanda krisis kemanusiaan dengan mengatasnamakan agama, sehingga sangatlah sensitif jika singgungan-singgungan yang terjadi berkaitan dengan agama.Olehnya itu pihak sekolah sebaiknya memikirkan hal ini, ataupun mencarikan solusi yang terbaik untuk menjawab kondisi tersebut.

\section{d. Pendidikan Multikultural}

Pendidikan Multikultural yang ataupun disebut juga dengan pendidikan keragaman adalah salah satu mata pelajaran yang mengajarkan tentang bagaimana memiliki pribadi baik, santun, berjiwa patriot, cinta tanah air dan beriman kepada Tuhan Yang Maha Esa.Pendidikan multikultural pada SMP Al-Hilaal Kamal diaplikasikan ke dalam mata pelajaran PKn.

\section{Menghargai Setiap Perbedaan dan Keragaman}

Ada terdapat berbagai keragaman di sekolah ini, baik dari segi perbedaan agama baik itu guru maupun siswa, ataupun perbedaan suku, serta budaya dimana wilayah ini merupakan salah satu daerah yang penduduknya bukan hanya penduduk lokal setempat.Sekolah telah menempatkan posisinya dengan baik sebagai institusi pendidikan, dimana pada kenyataannya sekolah ini mampu memelihara dengan baik sikap toleransi terhadap keberagaman. Sekolah harus terus menjaga kondisi ini agar supaya tujuan serta proses pendidikan karakter ini akan tercapai. Hal ini tidak lepas dari tepatnya cara penerapan serta pembinaan yang baik terhadap para peserta didik.

\section{Menanamkan Sikap Toleransi}

Sikap toleransi terhadap keberagaman yang telah ditunjukkan di sekolah ini adalah merupakan hasil dari proses usaha penerapan pendidikan karakter yang dilakukan oleh pihak sekolah. Guru bukan hanya bertindak sebagai pemberi mata pelajaran, melainkan guru juga terlibat langsung di dalam proses implementasi di lapangan untuk penanaman sikap toleransi. Sehingga menghasilkan sikap toleransi luar biasa yang bisa dilihat oleh masyarakat luas.

Sikap toleransi ini harusnya menjadi salah satu nilai plus yang menjadikan sekolah ini unggul dari sekolah-sekolah lainnya.Pihak sekolah dalam hal ini juga harus memerhatikan hal ini dimana dengan keunggulan ini bisa menjadikannya sebagai sesuatu yang menonjol baik itu di dalam promosi tahun penerimaan siswa baru maupun membuat siswa menampikan nilainilai ini dalam bentuk seni baik itu dalam bentuk pertunjukan puisi, teater dan sebagainya.

\section{e. Evaluasi Pendidikan Karakter}

Untuk mengetahui efektifitas dari suatu program yang sedang dijalankan maka perlu dilakukan evaluasi. Evaluasi adalah salah satu bagian yang terpenting dari sebuah proses. Begitupun dengan penerapan pendidikan karakter ini. 


\section{Penilaian Pendidikan Karakter}

Penilaian terhadap pendidikan karakter yang telah diterapkan selama ini adalah berada dalam kategori baik, karena didasarkan pada progres-progres baik yang telah ditunjukkan oleh sebagian besar siswa.Olehnya itu pihak sekolah harus bisa untuk menjaga dan lebih meningkatkan penerapan pendidikan karakter yang telah dijalankan selama ini.Dalam hal evaluasi, rutin dilakukan setiap akhir semester, namun secara individu bagi guru, ada baiknya dilakukan evaluasi setiap akhir pekan, agar supaya progres yang ditunjukkan oleh para peserta didik bisa terpantau dan bisa dilihat perubahannya setiap pekan.

\section{Masalah Yang Ditemukan Dalam Penerapan Pendidikan Karakter}

Dalam penerapan pendidikan karakter pada sekolah SMP Al-Hilaal Kamal ini pun juga memiliki beberapa masalah yang menghambat berjalannya pendidikan karakter dengan baik serta berbagai macam masalah lainnya yang memengaruhi baik dari segi eksternal maupun internal. Ada beberapa masalah yang ditemukan, diantaranya:

1. Masalah yang sangat besar dirasakan oleh para perancang pendidikan karakter pada sekolah ini adalah masalah infrastruktur. Selama ini kondisi sekolah ini boleh dikatakan dalam kondisi kurang, karena secara fisik gedung sekolahnya harus berbagi ruangan dengan sekolah dasar Al-Hilaal, dimana pada gedung sekolah SMP Al-Hilaal ini memiliki kualitas gedung yang semi permanen, dimana separuh dindingnya terbuat dari beton dan sebagian lainnya terbuat dari papan kayu. Hal ini juga bisa terlihat dari ruangan kepala sekolah. Namun oleh pihak sekolah menyiasatinya dengan mengecat agar supaya bisa terlihat rapih dan bagus. Kemudian kelengkapan infrastruktur yang masih kurang seperti laboratorium, komputer, serta tidak adanya tenaga keamanan sekolah juga masih menjadi batu sandungan di dalam penerapan pendidikan karakter ini.

2. Kurangnya tenaga pengajar yang juga mempengaruhi penerapan pendidikan karakter dimana jumlah tenaga pengajar pada sekolah ini masih sedikit.

\section{Solusi}

Dari beberapa permasalahan yang terjadi di dalam penerapan pendidikan karakter pada SMP Al-Hilaal Kamal ini haruslah dicarikan solusi, diantaranya :

1. Infrastruktur fisik mesti diperbaiki dan ruangan-ruangan pelengkap lainnya mesti diperhatikan, agar tingkat kenyamanan para peserta didik bisa meningkat di sekolah, selain itu hal tersebut juag bisa mendukung kinerja kepala sekolah beserta para guru untuk memudahkan pendidikan karakter.

2. Kerjasama yang baik mesti diperhatikan antara pihak sekolah, yayasan, serta komite sekolah. Baik dari segi komunikasi, 
koordinasi, dan evaluasi, Hal ini sangat diharapkan harus terjadi karena bertujuan untuk sama-sama mengawal proses berjalannya pendidikan serta penerapan pendidikan karakter yang baik bagi para peserta didik dari seluruh elemen sekolah. Sehingga dalam prosesnya, hasil-hasil evaluasi yang dilakukan dapat ditindak lanjuti untuk mencapai tujuan yang diinginkan bersama.

3. Tenaga pengajar yang berkualitas dan kreatif mesti ditambah, hal ini dimaksudkan agar dalam pelaksanaan pembelajaran akan membantu para peserta didik untuk bisa lebih memahami materi yang disampaikan serta dapat memengaruhi tingkat kenyamanan siswa di dalam kelas.

\section{f. Keterbatasan Penelitian}

Penelitian dilakukan dengan metode kualitatif dan menggunakan data primer yang diperoleh melalui wawancara mendalam.Keterbatasan pada penelitian ini meliputi subyektifitas yang ada pada peneliti. Penelitian ini sangat tergantung kepada interpretasi peneliti tentang makna yang tersirat dalam wawancara sehingga kecenderungan untuk bias masih tetap ada. Untuk mengurangi bias maka dilakukan proses triangulasi, yaitu triangulasi sumber dan metode. Triangulasi sumber dilakukan dengan cara cross check data dengan fakta dari informan yang berbeda dan dari hasil penelitian lainnya. Sedangkan triangulasi metode dilakukan dengan cara menggunakan beberapa metode dalam pengumpulan data, yaitu metode wawancara mendalam dan observasi.

\section{Kesimpulan, Implikasi dan Saran \\ 1. Kesimpulan}

Penerapan pendidikan karakter di SMP Al-Hilaal Kamal telah lama dilaksanakan dan hasilnya cukup baik, hal ini juga terlihat dari visi sekolah dimana sangat mementingkan aspek karakter.Namun belum semua siswa memiliki nilai-nilai karakter yang baik, hal ini dikarenakan oleh beberapa faktor diantaranya pemahaman guru yang belum begitu baik tentang pendidikan karakter, gedung dan ruangan sekolah yang belum memadai, serta minimnya kegiatan ekstrakurikuler bagi para peserta didik.

Kurangnya kerjasama antar pihak-pihak terkait terhadap penerapan pendidikan karakter mengakibatkan proses komunikasi dan evaluasi terhadap perkembangan pendidikan karakter peserta didik menjadi tidak optimal, sehingga mengakibatkan tidak adanya solusi dalam mengatasi setiap permasalahan yang terjadi di dalam pengembangan pendidikan karakter ini.

Kondisi fisik sekolah yang baik dan sarana penunjang yang memadai, tenaga pengajar yang kreatif dan pemahaman para guru tentang pendidikan karakter yang baik, ditambah lagi dengan kegiatan ekstrakurikuler yang cukup serta komunikasi yang efektif antara pihak sekolah, yayasan dan juga pihak komite sekolah adalah faktor yang penting di dalam implementasi pendidikan karakter di SMP Al-Hilaal Kamal. 
Implementasi Pendidikan Karakter Siswa (Studi Kasus di SMP AL-HILAAL Desa Kamal

Kabupaten Seram Bagian Barat)

\section{Implikasi}

a. Setelah melakukan penelitian ini, maka hasil dari penelitian ini kedepannya harus dilakukan penyebaran informasi kepada pihak SMP Al-Hilaal Kamal, pihak yayasan Pendidikan Al-Hilaal, pihak Komite sekolah, sekolahsekolah lain, serta Dinas Pendidikan Pemuda dan Olahraga Kabupaten Seram Bagian Barat. Dimana dengan pemberian informasi ini, maka pemahaman tentang implementasi pendidikan yang baik akan dipahami dan akan diterapkan di sekolah-sekolah lain sehingga pelaksanannya akan lebih efektif.

b. Penyebaran informasi ini dapat dilakukan dengan cara melaksanakan seminar di SMP Al-Hilaal Kamal, maupun sekolah-sekolah lainnya , dimana kombinasi antara pihak sekolah, serta komite sekolah maupun yayasan akan sangat membantu implementasi pendidikan karakter.

c. Juga melalui tulisan jurnal maupun atikel tentang faktor-faktor yang memengaruhi implementasi pendidikan karakter pada SMP Al-Hilaal Kamal.

\section{Saran}

a. Bagi pihak sekolah, hendaknya meninjau kembali penggunaan tenaga pengamanan sekolah, karena hal ini juga bisa membantu menekan angka peserta didik yang membolos.

b. Penempatan guru BK untuk menangani peserta didik yang memiliki masalah.

c. Membangun komunikasi yang intensif dengan pihak Dinas Pendidikan Pemuda dan Olahraga Kabupaten setempat agar permintaan untuk renovasi gedung sekolah bisa ditinjau dan direspon.

d. Bagi pihak yayasan, harus bersama-sama beserta pihak sekolah untuk mengawal semua proses pendidikan, karena hal ini juga merupakan tanggung jawab bersama agar pendidikan di SMP Al-Hilaal Kamal ini lebih baik dan maju.

e. Bagi pihak komite sekolah, juga hendaknya membangun komitmen yang baik dengan pihak yayasan serta sekolah untuk sama membangun pendidikan yang baik bagi para peserta didik.

\section{Daftar Pustaka}

Bungin,Burhan.2007.Penelitian Kualitatif: Komunikasi, Ekonomi, Kebijakan Publik dan Ilmu Sosial lainnya.Jakarta:Putra Grafika.

Moleong, J Lexy, Prof. Dr. 2009.Metode Penelitian Kualitatif. Bandung: PT. Remaja Rosdakaya.

Kementerian Pendidikan Nasional Badan Penelitian dan Pengembangan Pusat Kurikulum, (2010), Bahan Pelatihan : Penguatan Metodologi Pembelajaran Berdasarkan Nilai-Nilai Budaya untuk membentuk daya saing dan Karakter Bangsa, Jakarta : Hotel Mercure Ancol. 
Koesoema, A.D. 2012. Pendidikan Karakter Utuh dan Menyeluruh, Yogyakarta: Kanisius. Sugiyono, 2013. Metode Penelitian Kuantitatif Kualitatif dan $R \& D$. Bandung: Alfabeta.

UUD Pasal 31 tentang Pendidikan dan Kebudayaan Ayat 3 Undang-Undang Nomor 20 Tahun 2003, Sistem Pendidikan Nasional Undang-undang Nomor 17 Tahun 2007

Perpres No 87 Tahun 2017, Penguatan Pendidikan Karakter PP RI No. 55 Tahun 2007 https://news.okezone.com https://www.rappler.com 